\title{
Development of a parental report questionnaire for restless legs syndrome (RLS) in children: the $R L S Q$
}

Angela Evans ${ }^{1 *}$, Sarah Blunden ${ }^{2}$

From Australasian Podiatry Council Conference 2011

Melbourne, Australia. 26-29 April 2011

\section{Background}

Restless legs syndrome (RLS) in children is commonly reported, yet frequently undiagnosed. RLS can cause significant sleep disturbance and its associated deficits may have cardiovascular and neurocognitive consequences. Growing pains (GP) is often confused or synonymous with RLS, yet has been better researched and can be identified by parental questionnaire. RLS has not been able to be so distinguished, which renders an outstanding need. Therefore this study aimed to develop and validate a questionnaire to identify RLS, in children. The significance of this project is that RLS in children will be better identified in children for the first time.

\section{Methods}

A process of triangulation was undertaken to develop the RLS questionnaire. The literature, parent interviews and a children's focus group were the sources of initial data. Themes were extracted by independent review of the transcripts and the questionnaire was subsequently constructed and validated. The reliability of the questionnaire was examined using a same subject, repeated measures study.

\section{Results}

The interviews covered the parent's accounts of RLS in six children (two girls, four boys) all aged between eight and 10 years. The focus group obtained the experience of children suffering RLS. A questionnaire of 11 questions was developed and validated from a small

\footnotetext{
* Correspondence: angela.evans@unisa.edu.au

${ }^{1}$ School of Health Science, University of South Australia, Adelaide, SA, 5000, Australia

Full list of author information is available at the end of the article
}

convenience sample $(n=11)$. Internal consistency yielded $65 \%$ and repeat measures reliability $r h o=0.58$.

\section{Conclusions}

The questionnaire developed enables RLS to be identified in children specifically and for the first time. Such instrumentation may be used to establish prevalence, discriminate RLS from GP, to evaluate management programs and to assist treating clinicians.

\section{Author details}

'School of Health Science, University of South Australia, Adelaide, SA, 5000, Australia. ${ }^{2}$ Centre for Sleep Research, University of South Australia, Adelaide, SA, 5000, Australia.

Published: 20 May 2011

doi:10.1186/1757-1146-4-S1-015

Cite this article as: Evans and Blunden: Development of a parental report questionnaire for restless legs syndrome (RLS) in children: the RLSQ. Journal of Foot and Ankle Research 2011 4(Suppl 1):015.

Submit your next manuscript to BioMed Central and take full advantage of:

- Convenient online submission

- Thorough peer review

- No space constraints or color figure charges

- Immediate publication on acceptance

- Inclusion in PubMed, CAS, Scopus and Google Scholar

- Research which is freely available for redistribution

\section{(Ciomed Central}

